\title{
Home education as an alternative form of education in Poland: Management perspective
}

Aleksandra Berkowicz ${ }^{\star+}$ https://orcid.org/0000-0003-4387-7788

Abstract

*Jagiellonian University, Krakow, Poland. Email: aleksandra.zurowska@uj.edu.pl

Purpose. There is more and more literature dealing with home education, but this area still seems to be insufficiently explored. The aim of the article is to describe the processes and contexts of home education from the management perspective.

Design/methodology/approach. Initial recognition of the research subject through a literature review. A synthesising research approach was adopted, integrating the results of literature research and on this basis determining the directions of development of home education in Poland from specific perspectives.

Findings. One of the more interesting conclusions is the direction of changes in the law on home education: clear though slow changes towards liberalisation. Management of the educational process by parents is characterised by freedom, which translates into a variety of management styles, but two tendencies can be distinguished: conservative and liberal. Taking into account the historical aspect, the characteristic feature of home education today is its egalitarianism, not elitism.

Originality/value. The history of Polish education is quite complicated. Poland's enslavement by foreign countries resulted in many years of limiting education, including its various forms. Home education as an alternative to elementary schools was reactivated after 1989 and is still in statu nascendi. The article presents in a synthetic way the evolution of home education in Poland, thus outlining the trends in the development of home education from the perspective of management.

Keywords

homeschooling, education, education management.

\section{INTRODUCTION}

Home education was introduced into Polish education after 1989, as were nonpublic schools. For most of society, they were terra incognita; both home schooling and non-public education, although they have a centuries-old and vital tradition, were, with few exceptions, liquidated by PRL decision-makers for over forty years. The research question is: what changes is home education subject to, taking into account the historical, legal, and organisational factors?

This article provides a background to this subject containing definitions of home education and a short description of home education in the USA and in Western European countries. Characteristics of the historical, legal and organisational aspect of home education in Poland are then presented. The next section contains the results of the literature research. The conclusions indicate the limitations of the conducted research and include suggestions for future research.

\section{BACKGROUND}

M. Budajczak defines home education as "a variant of education in which parents take over from social factors total responsibility for education, becoming teachers for their children within the family home" (Budajczak, 2013). The teachers may be parents, persons with teaching qualifications, or persons who are not educated teachers. An extensive approach to this form of education is proposed by B. Śliwerski. In his opinion, "home education is based, among others, on replacing the specialist education of parents as organisers of the learning process, a strong emotional bond with the child, natural recognition of its developmental possibilities, interests and educational needs, providing interactive sources of knowledge (media, Internet), placing a strong emphasis on self-education and self-discipline, strengthening the sense of the child's self-worth, subjective approach to it and real dialogue with the child" (Dueholm, 2013). 
It is worth noting that in some countries around the world, home education is in the mainstream of education. The best example is the United States of America, where this phenomenon is legal in each of the 50 states and is the fastest growing form of education in the so-called K-12, that is, primary- and secondary-level education (Cooper, 2005). In 2019, the percentage of home-educated students of school age ranged from 3\% to 4\% (approximately 2.5 million school-age children (Ray, 2021), compared to $1.7 \%(850,000)$ of the student population in 1999 (National Center for Education Statistics, 2013). The phenomenon shows an upward trend. Currently, it is estimated that this percentage may range from $7 \%$ to $9 \%$ : from 4 to 5 million students of school age (Ray, 2021).

Home education is regulated by statute, not the US Constitution. Hence, the issues of educating children and adolescents are not uniform in the following areas: the presence of students at home classes, the content of teaching, parents' notifying the education authorities about the choice of this form of education, qualifications of teachers and taking exams.

Religious and moral education at school is one of the main reasons indicated by American parents for educating their offspring at home (34\% of respondents). Then, harmful school phenomena - lack of safety, drug addiction, negative pressure from peers ( $21 \%$ of respondents), dissatisfaction with teaching in educational institutions ( $17 \%$ of respondents) - and other reasons parents' free time, finances, distance from schools (14\% of respondents), providing children with a nontraditional approach to education ( $7 \%$ of respondents) and health reasons or special needs (6\% of respondents) (Zaise, 2013).

The state of home education in Europe varies by country. Great Britain stands out in terms of educational liberalism. Compulsory education, not compulsory schooling, is legally respected. In addition, parents are responsible for ensuring that their child of compulsory school age (from 5 to 16) receives full-time education appropriate to: a) their age and abilities, b) any special educational needs they have, either by regularly attending school or otherwise (Education Act 1996).

Local authorities in Great Britain do not register home schooled children (with the exception of reliable and justified information about the parents' failure to fulfill their obligation to educate their children and in the case of children with special educational needs) and do not interfere with the organisation of home schooling by parents (in providing local conditions, having teaching materials, appropriate qualifications of teachers, implementation of the program, plan, school standards related to the age of children, keeping documentation and maintaining contacts with educational authorities, passing school exams) (Kolasińska, Kuźmicka 2007). In fact, only the parents plan and coordinate their children's learning.

In continental Europe, the legislation allows home education in exceptional situations, such as disability or chronic illness of a child (in Germany only the child's state of health, and this in special cases only, entitles the student to study at home) (Kolasińska, Kuźmicka, 2007, p. 6-7). Organisational issues vary from country to country. In some countries, this form of education requires the approval of educational authorities and is supervised by state authorities (France), in other countries it is required that the person teaching have appropriate qualifications (Norway, Czech Republic). Elsewhere the student is required to take certain exams (Portugal, Norway) (Euridice, 2018).

In many countries, indirect forms of education, combining home education with school instruction, are acceptable. They include the so-called flexischooling, which assumes that the choice of the learning and teaching model belongs to the interested parties (Milerski, Śliwerski, 2000, p. 67). In addition, this type of education also consists in concluding a partnership agreement between parents and the school, in which the division of responsibilities in the field of education of the child is written (Meigham, 2012), as well as the cooperation of these two entities in carrying out educational activities is specified. In other words, the children attend school part-time during the regular period and spend the rest of the time in home education.

In the so-called Year-Round Education (YRE) model, schools are open all year round from 8 am to 8 pm, modeled on hospitals as support institutions open for many hours. According to their needs and interests, students can choose a variety of courses, workshops or timetables (Meigham, 2012) organised in these types of institutions.

In Poland, home education has its own specificity, which is influenced by history, legislation and its implementation in practice. These elements largely create an image of the management of this form of education.

\section{Home education - historical aspect}

Home education in Poland was reactivated after 1989, but it is one of the oldest forms of education. Parents have always more or less consciously passed on (and continue to pass on) knowledge to their children, while naturally fulfilling three basic functions: caring, educating and teaching. Nevertheless, home teaching based on the tutor's intentional didactic and educational activities was popular, especially among the wealthiest classes. Over time, home education and schooling "intertwined [...] and did not actually interfere with each other, complementing each other (e.g. often someone started learning at home and graduated from the university)" (Urban, 1994, p. 203). 
The choice of home schooling was determined by individual, social and political factors. The individual and social conditions included (Nawrot-Borowska, 2011):

- illness, physical or mental retardation of the child,

- providing a child with a higher level of education and upbringing by isolating it from the harmful effects of lower-born and poorer children.

Among the factors related to education policy there are (Nawrot-Borowska, 2011):

- a large distance from home to school,

- lack of space in schools.

In the second half of the nineteenth century and at the beginning of the twentieth century, the leading line of the partitioning policy was the denationalisation of Polish society. The family home was the only place where national subjects and the national language were taught (Nawrot-Borowska, 2011); these children were brought up in a patriotic spirit, maintaining the continuity of the nonexistent Polish state.

After regaining independence in 1918, the foundations of general education and the implementation of the principle of compulsory education began. Not only children who graduated from elementary schools were admitted to junior high schools, but also children from the so-called home preparation (Mauersberg, 1984). On the other hand, during the Nazi occupation, secret teaching was provided to all levels of schools. The forms of education used at that time included (in particular at the secondary school level) full-time learning and guided self-education (providing consultations, guidelines, self-study control). The classes were individual or collective.

In the People's Republic of Poland, the authorities sought to implement the socialist democratisation of education, which consisted in covering all children with school education, and expressed aversion to private education initiatives, which determined the exclusivity of education in state schools.

\section{Legal regulations of home education in Poland}

Home education in Poland has become legal since 1989. The Constitution of the Republic of Poland (Konstytucja RP), as an act of the highest legal force, provides that "parents have the right to raise their children in accordance with their convictions" (Article 48 (1)), "everyone has the right to education", "education is compulsory until the age of 18 , and parents have the right to choose schools other than public for their children "(Article 70 (1) and (3)). The first document regulating out-of-school education, which includes home education, was the Education System Act of September 7, 1991 (Ustawa 7 września 1991 r. o systemie oświaty).

Before the amendment to the act, the headmaster issued a permit to study outside the school, and specified the conditions necessary to fulfill this obligation. This was the wrong solution, as it could create a series of conflicts between the principal and the parents. During the 2009 meeting of the subcommittee on education, the Association for Education in the Family proposed several amendments related to the statutory provision on out-of-school education. Several of them have been included, among them, the proposal to delete the document in the form of a positive opinion of the psychological and pedagogical counseling center regarding the child to be educated at home. The members of the association justified their demand with several arguments. Firstly, they stated that the task of the counseling center is to advise, help parents and teachers, conduct therapy, and so on, and not to make decisions about how the child is educated. Secondly, leaving this provision would mean that the decision, which belonged to the director, was seemingly removed and the power to issue it passed to the counseling employee. Moreover, the activists of the association expressed concerns, supported by experience, that the basis of opinions issued by counseling centers is the positive or negative attitude of the counseling employee to home education (Propozycje poprawek zgłoszone przez Stowarzyszenie Edukacji w Rodzinie, 2009).

In the Act of 14 December 2016 on Education Law, the requirement to fulfill the obligation to pre-school education, compulsory education or the obligation to study outside the school institution is the submission by parents of an application and issuance of a permit by the headmaster of the school which the child should attend (Article 37 par. 1). The provisions of the act clearly define the conditions that must be met for a permit to be issued. Until recently, a permit for out-of-school education could be issued before the beginning of the school year or during its duration, if the issue is accompanied by three appendices: 1) opinion of a public psychological and pedagogical counseling center, 2) parents' declaration they will provide the child with conditions enabling the implementation of the core curriculum applicable at a given educational stage, 3) obligation of parents 
to join each school year by a child who meets the school obligation or the obligation to study for the annual classification examinations (Article 37 (2)). In 2021, the President of Poland signed an amendment to the Education Law, which abolished the requirement of zoning (that is, the child's place of residence in the province where the preschool or school facility where the child was admitted) and the obligation to attach the opinion of a psychological and pedagogical counseling center to the application (prezydent.pl). There is no information in the act on the period for which a home study permit is issued.

It is possible to withdraw the permit for home education in several cases: at the request of the parents, in the event of unjustified failure to take the child to the classification exams, failure to pass the annual classification exams, or in the event of the permit being issued in violation of the law (Article 37 (8)).

The legislation made it possible for home schooled children to participate in school activities: additional modern foreign languages (other than a modern foreign language taught at school), revalidation for disabled students, psychological and pedagogical support, activities developing students' interests and talents, and access to counseling professionals. In addition, ensuring access to textbooks, educational and exercise materials, teaching aids for the implementation of the core curriculum, and participation in consultations preparing for the annual classification exams are also offered (Article 37 (7)).

According to Polish law, home schooled children obtain annual classification marks on the basis of annual classification exams. Placement exams cover a part of the core curriculum applicable at a given educational stage, agreed for a given year with the school headmaster. These exams take place at the school where the headmaster has authorised him/ her to fulfill compulsory education or study outside the school. A student studying outside school does not receive a behavior grade. A more detailed description of the classification examination was included in the Ordinance of the Minister of National Education of April 30 , 2007. On March 31, 2015, this regulation was repealed. Currently, the classification examination is conducted in accordance with the provisions of the Education Act. A commission is appointed by the school headmaster to conduct the examination. The date of the classification exam is agreed upon with the parents and the student. It cannot be held later than on the day before the end of didactic and educational activities. If the student may not take the exam on the set date, for justified reasons, an additional time limit is set for him or her (Article 44I (1-4)).

A student may correct the grade in the event of a negative classification grade in one or two compulsory educational classes or classes in the language of a national minority, ethnic minority or a regional language. The director then appoints the committee again. The grade obtained from the resit examination is final. Failure of the student to pass the retake exam ends with the lack of promotion to a higher grade.

The pedagogical council, taking into account the educational possibilities of the student, may once during a given educational stage promote a student who has not passed the retake exam to a higher grade from one or two compulsory educational classes or classes in the language of a national minority, ethnic minority or a regional language, provided that these classes are carried out in a higher class (art. $44 \mathrm{~m}$ ). The student or parents may submit reservations to the school head if they believe that the annual classification mark for educational activities was determined contrary to the provisions on the procedure for determining the marks. Such objections are submitted from the date of establishing this assessment, at the latest within two working days from the end of didactic and educational activities. A committee appointed by the headmaster conducts a test of the student's knowledge and skills and determines the classification grade for the given educational activities. This assessment cannot be lower than the one established earlier and is final (except for a negative assessment). If the student, for justified reasons, did not take the test within the set time, he may take the exam on another date agreed to by the school head, the student and his parents. The student and parents may object to the obtained grade within five working days from the date of the resit examination (Art. 44n). By way of an ordinance, the minister for education and upbringing determines the detailed conditions and methods of assessing, classifying and promoting students, including the conditions, mode and form of conducting the qualifying examination. The types of classes for which the examination is not conducted is also under the discretion of the minister, as is the composition of the commission appointed to conduct the classification examination, taking into account the need to ensure the correctness of the examination and the proper documentation of its course. The case of the retake examination and the test of the student's knowledge and skills (Art. 44zb, sections 6-8) is subject to the same regulations. Some of the parents of the students taking the placement exams were disappointed with the way they were "enforced to obey the system" (Janicka-Galant, 2015). In other words, the exams tested encyclopaedic knowledge, excluding creative thinking, problem-solving skills or the possibility for home-educated children to present their achievements and projects throughout the year. Moreover, parents of home-educated children sought to amend the regulations by abolishing annual examinations and introducing them after full didactic cycles: after the third and sixth grade, and after lower secondary and upper secondary school (matura exam). According to them, this would allow them to be more flexible in introducing issues tailored to the child's level of development and interests (Janicka-Galant, 2015). 


\section{Organisational aspects of home education}

The choice of the discussed form of education is difficult because it requires the involvement of parents in the education of their offspring and partial or complete resignation from professional ambitions of at least one of the parents, if he is a teacher. In 2013, data on Polish home-teaching families were not registered by nongovernmental organisations, and the statistics of the education authorities were imprecise. However, it was estimated that the total number of parents and children deciding on home education was around a few hundred people (Konowrocka, 2013). According to the data of the Ministry of Education from $2017,13,955$ (0.3\% of all students in schools) are studying at home (Stowarzyszenie Edukacji Domowej w Rodzinie, 2021). A slow increase in the number of people choosing this form of education is forecasted. This quite demanding method of education, especially for parents who are responsible for organising such a time-consuming process, must result from a high level of motivation. Human freedom is assumed to be the primary reason for undertaking home education. P. Bartosik notes that "the supporters of home education in Poland do not want to prove that the school is bad. They just want to highlight the importance of freedom of choice in making decisions about a child's education" (Bartosik, 2009, p. 49). M. Budajczak divides parents' motivations to undertake home education into three categories: didactic motives, educational motives and caring motives (Budajczak, 2004). He then divides each of these principal motives according to positive and negative causes. The characteristics of individual motives are presented in the table below.

Table 1. Motivations for choosing home education.

\begin{tabular}{lll}
\hline \multicolumn{1}{c}{ Types of motives } & \multicolumn{1}{c}{ Positive } & Negative \\
\hline Didactic motives & $\begin{array}{l}\text { An individual approach in home education allows } \\
\text { you to learn about the child's predispositions, } \\
\text { develop their abilities and work on deficits }\end{array}$ & $\begin{array}{l}\text { Ineffectiveness or low didactic effectiveness of } \\
\text { public schools, caused by systemic factors and } \\
\text { working conditions }\end{array}$ \\
\hline Educational motives & $\begin{array}{l}\text { The home-schooling program correlates positively } \\
\text { with the parents' worldview }\end{array}$ & $\begin{array}{l}\text { Vagueness of the worldview of schools and (or) } \\
\text { spreading by schools of values that are in contra- } \\
\text { diction with the parents' belief group, which causes } \\
\text { confusion and duality of the child's reality }\end{array}$ \\
\hline Caring motives & $\begin{array}{l}\text { Parents' sense of responsibility for ensuring their } \\
\text { child's optimal development }\end{array}$ & $\begin{array}{l}\text { Physical, mental and moral threats from peers, } \\
\text { teachers or people from outside the school envi- } \\
\text { ronment }\end{array}$ \\
\hline
\end{tabular}

Source: Budajczak, M. (2004). Edukacja domowa. Gdańsk: GWP, pp. 86-90.

Therefore, the main reasons for home schooling are shortcomings in the activities of schools and the desire to direct the education of children in a way that ensures their harmonious and comprehensive development.

In home education, the organisation of education is defined differently than in a conventional school, although the language and nomenclature of the basic components of school and home education are the same. At the heart of home education is the student who influences the surrounding reality. This means that he is or may be a co-author of the concept of education, he has the possibility to co-decide or decide about many elements of the educational process. At the same time, the parentteacher shuns the grading system adopted in schools. Assessment in home education involves the work process, not just the end result. The mistakes made by the child are discussed on an ongoing basis and attention is paid to the assessment of partial successes in order to positively motivate and encourage the child to overcome learning difficulties (Budajczak, 2004. p. 91 ).

The range of teaching measures used in home education is very wide. Parents and children use school textbooks, as well as popular science and fiction books, magazines, encyclopaedias, and dictionaries as well as television, film, internet sources and educational programs. They also visit various scientific and cultural institutions more often than school students. Moreover, in home teaching, traditional teaching aids are often used, such as a blackboard or notebooks (Budajczak, 2004, p. 94-96).

The organisation of education is the responsibility of the parents. In some families, the day begins with the implementation of the compulsory school curriculum, although it is not strictly defined, as are the time of work of children on a given topic and the place where education takes place. Very often, children translate the acquired knowledge into practical activities or gain knowledge through experience. Parents usually try to organise education adapted to the "natural rhythm of life" of a person. For example, below are excerpts from the description of the organisation of home schooling in two families.

In one of them, "around at 8.00 am lessons start. All the children gather in the dining room. Most often, they first work on the compulsory school curriculum, with textbooks, unless the children want otherwise, because in such a school they may have their opinion on this matter. Then they spend longer reading and the next day there is more math. If the geography lesson is about the San River, Veronica herself searches for information on this topic in an encyclopaedia or the Internet. [...] The favorite activities of all children are either reading together or doing a theatre. [...]. During one of the walks, Małgorzata walked with 
the children in the meadow, with an atlas of insects in her hand. [...] The children saw with their own eyes the six-spot krasnik, instead of memorising how many legs and wings it has. [...] The nearby meadows and forests are often places for nature lessons" (Stelmach, 2008, p. 103).

In the second family, on the other hand, the organisation of education is as follows: "After a shared breakfast [...] seven-yearold Mateusz starts lessons. Four-year-old Ania participates with interest in everything. In the morning, the boy is able to focus longer, so from 9.00 to 11.00 they do the school curriculum. [...] How do home educated children change a light bulb? They read the history of Edison's invention. Then they find out how electricity is produced and build a model of the ladder that is needed to replace the bulb. They learned biology by planting a potato under a block and watching it grow (Stelmach, 2008, p. 103). Home learning, as a form of education that was revived after more than forty years, caused concern among some Polish teachers, educators and even parents. Uncertainty was caused by such issues as socialisation of home-educated children, and learning outcomes. In North America, where home education has been developing for several decades, scientists have started working on a better understanding of this issue. The results of many studies have shown that there are no statistically significant differences in the social and emotional development or self-esteem of children educated at home and at school (Kelly, 2008). Moreover, for example, P. Basaham's research carried out in 2001 showed that children learning at home are friendlier, independent, socially developed and have higher self-esteem than children learning in public and private schools. The author of this paper suggested that children learning at home with their parents receive greater socialisation benefits than students attending school (Kelly, 2008). Most of the families choosing this form of education belong to the so-called large families who care about "children's emotional stability, self-esteem and altruism" (Strzelecka, 2013). The socialisation of homeraised children takes place through various contacts. Most of them participate in activities organised outside the home, use cultural and educational institutions: libraries, community centres, museums, theatres and parks.

Another area scientifically penetrated within home education is the effects of education. Available research by homeschoolers' associations (Homeschool Progress Report, 2009) as well as by independent researchers (Dewar, 2011) support the thesis that school achievement is higher for home-educated children. S. Martin-Chang, O. N. Gould, and R. E. Meuse conducted a study of home- and school-educated children.

Homeschooled children were divided into: structured homeschoolers and those who did not participate in such organised activities (unstructured homeschoolers). The researchers selected two groups to compare: 1) children from the so-called structured home schooling and school children, 2) children with structured and unstructured home schooling. In the first comparator group, home-educated children achieved higher scores in various fields of study, compared to those in conventional education. In the second case, children without organised home education achieved lower than expected test results. In addition, children with structured home education scored significantly higher than children with unstructured home education (Martin-Change, Gould, Mense, 2011).

It happens that doubts about home education also refer to the parents' lack of competence to teach their children. This is contradicted by the educational success of children using this form of education. In Poland, the majority of children educated at home who take primary and lower secondary school exams receive very good and excellent grades (Budajczak, 2004 pp. 70-75). In addition, it should be remembered that in home education, the teacher can be a parent, but also another person from outside the family circle. In practice, some families using this form of education conduct joint activities for children, in which one parent teaches chemistry, the second one teaches history, the third teaches mathematics, and so on.

At the end, I would like to mention the positive and negative sides of home education formulated by parents - practitioners. The pluses include (Anulak, 2009, pp. 10-11):

- influencing the child's character,

- ensuring safety and building self-worth by the child,

- developing his strengths and interests,

- better results in teaching and a favorable atmosphere,

- better time management (no additional, time-consuming organisational activities at school, such as checking the attendance list),

- $\quad$ strengthening family ties,

- developing social intelligence,

- $\quad$ active forms of spending free time,

- development of self-knowledge in children,

- $\quad$ shaping positive characteristics in parents, such as duty, responsibility, regularity, creativity, as well as overcoming one's weaknesses.

- The cons are (Anulak, 2009, pp. 11-12): 
- reducing parents' free time (parents must first prepare themselves for the lesson),

- reduction of the household budget by the resignation of one of the parents from work, most often,

- difficulties with the child's discipline (dual role of mother and teacher),

- no reference of the child's work to peers and thus the disappearance of the motivating factor, which is competition,

- no contact of the child with teachers and enthusiasts.

\section{RESULTS}

The research concept adopted in this article synthesises and integrates knowledge about home education in Poland to explore, describe and explain the transformation of this form of education from the management perspective. Therefore, a research question was asked: what changes have occurred in home education, taking into account historical, legal, and organisational factors.

The following factors contributed to undertaking home education in former Poland: inefficient management of educational policy - lack of space in schools, long distance between home and school - and individual and social factors - a child's disease, the desire to provide the child with a good education through isolation from socially inferior children. Currently, the use of home education is determined by the decision of parents, who choose this form of education mainly because of their worldview and feeling of responsibility for the child's development. From a historical perspective, home education today is not elitist but egalitarian, and it is often a manifestation of freedom in choosing the form of education for your children.

Today, home education is largely a civic initiative. Parents choose this who are not only responsible for their children's education but also for managing the educational process, very often performing several roles at the same time: the person managing the child's education, the teacher and the parent.

In recent years, there have been changes in the Polish legislation regulating home education. Polish law sets out the requirements and outlines the framework for managing the education process of home-educated children. Before 2021, parents applied together with a declaration of providing the child with the conditions enabling the implementation of the core curriculum, and a commitment to take the child to annual classification exams. They also needed a positive opinion from the psychological and pedagogical clinic. Currently, the obligation to attach the opinion of the counseling centre has been abolished, as has the requirement of zoning, which proves changes towards the liberalisation of the law on home education. Thus, the number of entities participating in the decision-making process regarding permission to study at home has decreased. In addition to the education authority that regulates this, the principal and parents are the entities involved in meeting the formal requirements. The initiators of changes in the legal area are nongovernmental organisations related to home education, home educators, and supporters of this form of education, who have postulated several legal simplifications in this area for many years.

Parents are responsible for managing the implementation of the home education process understood as classic management functions: planning, organising, motivating, and controlling. The law does not interfere with the selection of methods, means, and ways of assessing children. Parents decide or co-decide with their children about the work schedule (e.g., hours of study, days; places: outdoor, home or perhaps a museum), methods, means, additional content, methods of assessing children, the person teaching, and other participants in education. Therefore, we can distinguish several styles of home education management by parents. Two of the basic styles are conservative and liberal (Konowrocka, 2013). The conservative style largely reflects the institutional school rhythm of work, in which teaching is based on a prepared timetable and appropriate textbooks. Liberal style is characterised by great freedom in education and spontaneous management of children's education.

\section{CONCLUSIONS}

The aim of the article was to present the issue of home education by capturing the elements of managing this form of education. This article is an attempt to fill the research gap concerning the lack of studies on home education from the management perspective. It also outlines the direction of future empirical research that would concern various aspects of managing the process of educating children by home-educating parents.

It is impossible in this text to discuss the entirety of home education in Poland, therefore only selected issues relevant to the purpose of this article are highlighted. This is undoubtedly a limitation of the research carried out. Moreover, the research results are based on literature research and no new empirical research has been conducted in this area. 
Home education in Poland is an alternative, niche education, not mainstream, due to the number of children using this form. The modest database and the lack of research on the characteristics of families choosing this form of education are a challenge for future researchers. Also, the theoretical research presented in this article and the results described are the starting point for undertaking research in the field of home education process management.

\section{REFERENCES}

Anulak, M., Anulak, Z. (2009). Nasza edukacja domowa In M. Anulak, Z. Anulak (Eds.), Edukacja domowa w Polsce. Teoria i praktyka. Warszawa: Oficyna Wydawniczo-Poligraficzna "Adam".

Bartosik, P. (2009). Dlaczego edukacja domowa? In M. Zakrzewska, P. Zakrzewski (Eds.), Edukacja domowa w Polsce. Teoria i praktyka. Warszawa: Oficyna Wydawniczo-Poligraficzna "Adam".

Budajczak, M. (2004). Edukacja domowa. Gdańsk: GWP.

Budajczak, M. (2013). Stowarzyszenie edukacji domowej. http://www.edukacja.domowa.pl/.

Cooper, B.S. (2005). Homeschooling in Full View: A Reader. Charlotte, NC: Information Age Publishing.

Dewar, G. (2011). Homeschooling outcomes: How do they compare? Parenting Science http://www.parentingscience.com/homeschoolingoutcomes.html\#sthash.0jfb6x3h.dpu.

Dueholm, N. (2013). Polityka oświatowa państwa nie powinna naruszać terytorium rodziny - rozmowa z prof. B. Śliwerskim, http://www.edukacjadomowa.piasta.pl/sliwerski.html. Education Act 1996 c. 56, Part I, Chapter I, Compulsory education, Section 7, http://www.legislation. gov.uk/ukpga/1996/56/section/7.

EURIDICE Report. (2018). Home education: Policies in Europe: primary and lower secondary education, https://eurydice.org.pl/wp- content/ uploads/2018/10/home_education_in_europe_report.pdf.

Homeschool Progress Report 2009: Academic Achievements and Demographics. (2009). HSLDA, http://www.hslda.org/docs/study/ ray2009/2009_ray_studyfinal.pdf.

Janicka-Galant, A. (2015). Krok dziesiąty - egzaminacyjna paranoja, http://edukacjadomowa.monomit.pl/podroz-z-dzieckiem-przez-swiatwiedzy/krok-dziesiaty-egzaminacyjna-paranoja.

Kelly, A.E. (2008). Pioneers on the home front: an exploratory study of early homeschoolers in Hawaii, 2008, http://scholarspace.manoa.hawaii. edu/bitstream/handle/10125/20525/HAWN\%20ACI_5108_r.pdf?sequence=1.

Kolasińska, E., Kuźmicka, J., Smoczyńska, A. (2007). Edukacja domowa - raport Eurydice (pp.6-11). Warszawa: Fundacja Rozwoju Systemu Edukacji.

Konowrocka, D. (2013). Najczęściej zadawane pytania dotyczące edukacji domowej, http://www.edukacjadomowa.pl/faq2.html.

Konowrocka, D. Zjazd podwarszawski (1997). http://www.edukacjadomowa.piasta.pl/zjazd8.html.

Konstytucja RP, Dz. U. (1997). nr 78 poz. 483, http://www.sejm.gov.pl/prawo/konst/polski/kon1.htm.

Martin-Chang, S., Gould, O.N., Mense, R.E. (2011). The impact of schooling on academic achievement: evidence from homeschooled and traditionally schooled students. Canadian Journal of Behavioral Science, 3.

Matusak, P. (1997). Edukacja i kultura Polski podziemnej 1939-1945. Siedlce: Instytut Historii Wyższej Szkoły Rolniczo-Pedagogicznej w Siedlcach, Muzeum Historii Polskiego Ruchu Ludowego w Warszawie, Siedleckie Towarzystwo Naukowe.

Mauersberg, S. (1984). O szkołę jednolitą i demokratyczną. In J. Miąso (Eds.), Historia wychowania. Wiek XX. Warszawa: PWN.

Meigham, R. (2012). Flexi-schooling, year-round education and cyber schools, http://www.rolandmeighan.co.uk/resources/Flexischooling.pdf. Milerski, B., Śliwerski, B. (2000). Pedagogika. Warszawa: PWN.

National Center for Education Statistics. (2013). http://nces.ed.gov/fastfacts/display.asp?id=91. 